\title{
"The impact of remittances on household savings in the Baltics"
}

\begin{tabular}{|c|c|c|}
\hline AUTHORS & \multicolumn{2}{|c|}{ Andrej Přivara (D https://orcid.org/0000-0001-9737-7338 } \\
\hline ARTICLE INFO & $\begin{array}{l}\text { Andrej Prívara and Karol Trnovs } \\
\text { household savings in the Baltics } \\
\text { Innovations, 18(1), 335-345. doi }\end{array}$ & $\begin{array}{l}\text { Jact of remittances on } \\
\text { gement and Financial } \\
\text { ). } 2021.27\end{array}$ \\
\hline DOI & http://dx.doi.org/10.21511/imfi.1\& & \\
\hline RELEASED ON & Tuesday, 23 March 2021 & \\
\hline RECEIVED ON & Saturday, 20 June 2020 & \\
\hline ACCEPTED ON & Tuesday, 16 March 2021 & \\
\hline LICENSE & $\begin{array}{l}(\mathrm{coc}) \mathrm{EY} \\
\text { This work is licensed under a C } \\
\text { License }\end{array}$ & Attribution 4.0 International \\
\hline JOURNAL & "Investment Management and $\mathrm{F}$ & \\
\hline ISSN PRINT & $1810-4967$ & \\
\hline ISSN ONLINE & $1812-9358$ & \\
\hline PUBLISHER & LLC "Consulting Publishing Cor & "erspectives" \\
\hline FOUNDER & LLC "Consulting Publishing Cor & "erspectives" \\
\hline$\sigma^{0}$ & 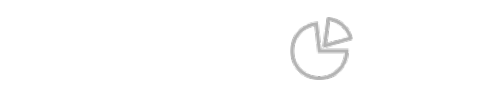 & $\begin{array}{l}\text { ニニミ } \\
\text { ニシこ }\end{array}$ \\
\hline NUMBER OF REFERENCES & NUMBER OF FIGURES & NUMBER OF TABLES \\
\hline 57 & 3 & 5 \\
\hline
\end{tabular}

(c) The author(s) 2022. This publication is an open access article. 


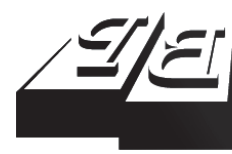

BUSINESS PERSPECTIVES

(O)

LLC "CPC "Business Perspectives" Hryhorii Skovoroda lane, 10, Sumy, 40022, Ukraine www.businessperspectives.org

Received on: $20^{\text {th }}$ of June, 2020 Accepted on: $16^{\text {th }}$ of March, 2021 Published on: $23^{\text {rd }}$ of March, 2021

๑) Andrej Př́vara, Karol Trnovský, 2021

Andrej Př́vara, Ing., Ph.D., Assistant Professor, Department of Social Development and Labour, the University of Economics in Bratislava, Slovakia. (Corresponding author)

Karol Trnovský, Ing., Ph.D., Assistant Professor, Department of Economics, the University of Economics in Bratislava, Slovakia.

\title{
THE IMPACT OF REMITTANCES ON HOUSEHOLD SAVINGS IN THE BALTICS
}

\begin{abstract}
Proper understanding and monitoring of household savings are crucial to effective macroeconomic policies targeted at balanced and sustainable economic growth. Remittances, as a financial flow of foreign capital, can create a vital part of private savings. This paper is aimed at identifying whether remittances contribute to household savings in the Baltics along with other macroeconomic variables in a post-crisis period, during which the relative smoothing and convergence of economic development of the Baltic countries after the sharp financial distress in 2009 can be observed. The following methods of panel data regression analysis were employed: fixed effects and OLS. The results of the econometric analysis based on both fixed effects and OLS methods reveal that remittances are an essential driver of savings in the Baltics in the long run. Savings in the Baltics are not significantly influenced in the short term by sharp economic fluctuations, but are dependent on demographic factors and foreign capital, which can bring instability in economic development and financial flows of the region.
\end{abstract}

\section{Keywords}

JEL Classification economic fluctuations, remittances, drivers, development

E21, H32

\section{INTRODUCTION}

Remittances account for a significant part of foreign capital flows in developing countries. Remittances are considered to have a positive effect on the economy and be beneficial for development (e.g. Aguinas, 2006, Ghosh, 2006). However, it is not clear enough how remittances affect different aspects of wealth of a recipient economy. The study of the Asian Development Bank and the World Bank (2018) has documented that remittances are acyclical regarding the recipient state. Remittances appear to be less volatile than other types of financial flows, including both foreign direct investment (FDI), and official development assistance (ODA) and export (Gavurova et al., 2020). However, they are more procyclical than ODA and less procyclical than financial flows. Remittances demonstrate flexibility during sudden financial crises and breaks and remain steady, whereas total financial flows drop abruptly during such episodes, thus, offsetting the effects of volatile financial flows. Households that receive international remittances spend more on health, education and housing than those that do not. Remittances also contribute to smoothing out consumptions of receiving households and facilitating them to mitigate sudden economic disaster better.

The main issue of remittances regarding development is that the majority of remittances are spent on consumption, and minimal share is invested (Basu \& Rajan, 2018). It should be noted that recently the spending on education and health of remittance-receiving households is considered as investment in human capital as in the long run they contribute to the capacity development of labor force in the country. 
Remittance-receiving households tend to raise their spending on education and health if they obtain more significant amounts of remittances. From this point of view, remittances are spent not only for consumption, but also contribute to the labor productivity (Akter, 2018; Matuzeviciute \& Butkus, 2016) and the total factor productivity of the country (Kumar \& Stauvermann, 2014; Kumar et al., 2018). According to studies, remittances often appear to be more beneficial for local economies than FDI and ODA (Makhlouf, 2019).

When investments considered as financial investments, such as securities or savings, benefit from remittances at a macro level, investing them in public goods such as physical infrastructure is the better path. In turn, low savings rate, in particular, household savings can create concern for policymakers due to the following reasons. First, the household sector is a primary sector of the national economy that contributes to savings. Second, household savings may finance domestic and foreign investment, contributing to economic growth and development. Third, goods in the form of savings can shift efficiently from generation to generation. Fourth, saving behavior of households is also crucial for monetary authorities and financial institutions. The overall amount of household savings influences not only the final consumption of households, hence demand of the retail loans, but also banks funding model, interest rates, exchange rates, current account balance and the resilience of the economy to shocks. Therefore, proper understanding and monitoring of the household savings are crucial to developing and implementing efficient macroeconomic policies targeted at balanced and sustainable economic growth. A low household savings rate can indicate fewer job creations, and therefore a lower quality of life. Remittances, as a financial flow of foreign capital, can create a vital part of private savings.

This paper is aimed at identifying whether remittances contribute to household savings in the Baltics along with other macroeconomic variables in a post-crisis period, duirng within which the relative smoothing and convergence of economic development of the Baltic countries can be observed after sharp economic distress in 2009.

\section{LITERATURE REVIEW}

\subsection{The effect of remittances on household savings}

The empirical literature in most cases indicates a positive association between household savings and remittances across countries (Ashraf et al., 2014; Esteves \& Khoudour-Casteras, 2011; Iheke \& Aniocha, 2017). In particular, Gani (2016) has found a positive connection between remittances and private savings in selected Asian countries. Haider et al. (2016) have explored the effect of remittance on consumption and the savings behavior of rural households in Bangladesh and found out a substantial impact of remittances on consumption and savings. Baldé (2011) concluded about a significant positive impact on savings in Sub-Saharan Africa during 1980-2004. Quartey et al. (2019) have investigated the linkages between remittances and households savings in Ghana and concluded that households receiving international remittances have a higher probability of savings comparing to households that obtain only domestic remittances. Raza (2015) explored the influence of FDI and workers' remittances on the private savings of Pakistan and concluded about FDI and workers' remittances having a considerable positive impact on private savings in both short and long perspectives. Causality analyses have confirmed the bidirectional causal relationship between FDI and remittances with private savings.

Some studies highlight the negative influence of remittances on savings due to the indicated positive influence on consumption. In particular, Devasagayam et al. (2016) have argued about the negative impact of remittances on domestic savings by researching their connection in the Middle East and North Africa (MENA) countries between 1977 and 2014. They concluded about the positive impact of remittances on the economic growth through stimulating household consumption that increases the expected consumption and may increase imports, which cuts savings owing to low levels of income. For the same region, Sabra (2016) 
has studied the impact that remittances have on investment, household savings and economic growth. It was found out that remittances had a positive influence on growth through stimulating family consumption that may rise imports, which cuts savings under the low levels of income.

\subsection{Remittances in the Baltics}

There is vast literature that explores the impact of remittances on economic growth indicating their relatively positive influence on the economy of receiving countries and the development of the countries of different income levels (Arif et al., 2019; Carment \& Calleja, 2018; Chezum et al., 2018; Grabowska et al., 2017; Maduekwe \& Adesina, 2017; Meseguer et al., 2017; Pajaron, 2017; Wadood \& Hossain, 2017; Dvorský et al., 2019). However, they pay little attention to their influence on household savings and, in particular, in the Baltics region. The Baltics region, along with Romania and Bulgaria, represents a region with lower household saving rates when compared to other EU region countries, whereas the remittances are higher than in other more developed member states. After EU enlargement in 2004, the remittances in the Baltics have increased considerably. However, after the crisis of 2008, they remained stable, ranging from 1.72 to $2.25 \%$ of GDP. On the other hand, savings in EU15 countries are considerably higher (13-15\% of disposable income) and remittances are significantly lower (less than $1 \%$ of GDP) (World Bank, retrieved on October 29, 2019).

According to Strielkowski et al. (2018), international migration and remittances have a considerable positive impact on the economic development of the Baltic states in comparison with other macroeconomic factors. An OECD study on emigration in the Baltics highlights the significance of remittances for households, particularly during the world financial crisis of 2008 , as remittances mitigated the consequences of the crisis, as well as compensated for financial distress, especially in Lithuania (OECD, 2013). Azam (2016) has studied the impact of remittances on poverty alleviation in a global perspective, including Baltic countries, and found out there are substantial possible benefits related to foreign remittances for poor people. The regional research of Zuniga (2011) has shown that remittances play a vital role in the economy of countries, including the Baltics. Independent of the role of institutions, remittances positively influence economic growth; however, they are used for consumption rather than savings. The results of Kumar and Stauvermann (2014) have demonstrated that in Lithuania, the remittances have a dynamic short-run and a significant long-run effect on the output per worker. Moreover, the causality analysis has shown a mutually underpinning effect between the output per worker and capital per worker, as well as unidirectional causality from remittances to output per worker.

Thus, remittances have an undoubted effect on the economy. However, there is no consensus about the nature of their influence on the savings rate, hence giving grounds for further research.

\subsection{Factors affecting household saving behavior}

\subsubsection{Economic factors}

Unemployment rate and inflation are the most widely used indicators for assessing the influence of uncertainty on household savings. When anticipating economic distress, households tend to save more as a mitigating measure. An increase in the unemployment rate and inflation increases the volume of household savings (Kostakis, 2013; Syed et al., 2017; Temel Nalın, 2013a). Temel Nalın (2013b) investigated the drivers of household saving and portfolio choice behavior in Turkey using the inflation index and concluded that inflation increased the probability of household saving. Niculescu-Aron and Mihăescu (2012) employed first-order differences in the inflation rate in two panels of the states - Western Europe and Central and Eastern Europe. They found out in both panels that a rise in inflation was positively associated with household savings.

Fiscal policies may have a considerable effect on household savings. Active fiscal policies aimed at stimulating consumption can adversely affect the savings. To stimulate the economy, the government can increase government expenditure and run a budget deficit, which may decrease present household consumption expenditure if households anticipate future tax rises to support public debt (OECD, 2018). An assumed consumption smoothening, a drop in the expected future in- 
come will decrease current consumption and rise current household savings. The fiscal policy of the states is assessed by the rate of the government surplus in \% of GDP, rate of public debt in \% of GDP, social protection expenditures by the government in \% of GDP and the portion of indirect taxation in total taxation.

The net inflow of FDI is negatively associated with household saving. Hence, FDI seems to be a substitute for domestic saving (Rocher et al., 2015).

\subsubsection{Demographic factors}

The concept of consumption smoothing over a lifetime suggests that young people tend to save less than adults. Elderly individuals are likely to dissave. Thus, countries with high age dependency are likely to have lower household savings (Edwards, 1995; Loayza et al., 2000).

An increasing life expectancy may also affect households savings. Demographic projections show that the population is rapidly ageing in many of the EU member states. Therefore, households may rise their savings as they face a longer retirement. Thus, life longevity can also be a potential driver to capture this effect (Bloom et al., 2002; Carvalho et al., 2017). Often, older people live alone, which drops their disposable income. Therefore, assuming that women are over-represented among the older age group of the population, their saving rates may be negatively related to life expectancy (OECD, 2017).

\subsubsection{The effect of financial literacy on household saving behavior}

Financial literacy is another critical factor that influences households saving behavior. Shortage of primary financial education may be related to the lack of sufficient retirement planning and lack of wealth accumulation (Reisch \& Zhao, 2017). It may as well cause the loss of the link between households and financial institutions, hence causing information asymmetry. There is also a positive association between household savings and financial literacy, wealth accumulation and retirement planning (Ameriks et al., 2002; Hastings et al., 2013; Lusardi \& Mitchell, 2011; Lusardi, 2004; Stango \& Zinman, 2009; van Rooij et al., 2011). Jappelli and Padula (2013) have identified that individuals benefit from investment in financial literacy as financial literacy contributes to an increase in wealth returns. Batsaikhan and Demertzis (2018) have indicated that in the developed countries, there is a positive association between savings, the borrowing balance of the country and the level of financial literacy. In Denmark and Sweden, which are the countries with the highest financial literacy rates, almost all respondents reported doing savings at a financial institution in the last 12 months. The authors have also indicated that the financial literacy rank has a positive linkage to both saving borrowing and behaviors, representing that in countries with higher literacy rates, adults have a higher active link with financial institutions.

\section{METHODOLOGY}

\subsection{Model specification}

Based on the theoretical grounds and empirical findings, a regression model was used to assess the impact of remittances on household saving behavior in the Baltics along with other macroeconomic determinants (Table 1) annually in the post-crisis period from 2010 to 2017. For the regression analysis panel data was employed with the use of the following methods: fixed effects and OLS.

The model equation is as follows:

$$
\begin{aligned}
& \text { Savings }=\alpha_{0}+\alpha_{1} l_{-} \text {Remittances }+ \\
& +\alpha_{2} l_{-} \text {Life_expect }+\alpha_{3} \text { Unempl_perc }+ \\
& +\alpha_{4} \text { Old_age_depend }+ \\
& +\alpha_{5} \text { Inflation_HICP }+ \\
& +\alpha_{6} \text { FDI_Inflow }+\alpha_{7} \text { Gov_debt }+ \\
& +\alpha_{8} N S_{-} \text {fin_edu }+U_{i} .
\end{aligned}
$$

\subsection{Data: Common economic features of the Baltics}

Latvia, Lithuania and Estonia share a similar history and development aspects. The countries took back their independence from the Soviet Union in the early 1990s before EU accession in 2004. The Baltic countries show key similarities regard- 
Table 1. Description of variables

\begin{tabular}{|c|c|c|c|c|}
\hline Variable & Description & Unit of measure & Source & $\begin{array}{l}\text { The expected sign of the } \\
\text { influence on savings }\end{array}$ \\
\hline $\begin{array}{l}\text { Savings: dependent } \\
\text { variable }\end{array}$ & The gross saving rate of households & $\begin{array}{c}\text { \% of gross } \\
\text { disposable income }\end{array}$ & (Eurostat) & \\
\hline I_Remittances & Remittances in receiving countries & $\begin{array}{l}\text { Millions of US } \\
\text { dollars }\end{array}$ & (World Bank) & + \\
\hline I_Life_expect & Life expectancy at the age of 65 & years & (Eurostat) & + \\
\hline Unempl_perc & The unemployment rate & $\begin{array}{c}\% \text { of the active } \\
\text { population }\end{array}$ & (Eurostat) & + \\
\hline Old_age_depend & $\begin{array}{l}\text { Old dependency ratio: population } 65 \text { and } \\
\text { over to population } 15 \text { to } 64 \text { years }\end{array}$ & ratio & (Eurostat) & - \\
\hline Inflation_HICP & $\begin{array}{l}\text { Harmonised Indices of Consumer Prices, } \\
\text { annual average rate of change }\end{array}$ & $\%$ & (Eurostat) & + \\
\hline FDI_inflow & Foreign direct investment, net inflows & $\%$ of GDP & (World Bank) & - \\
\hline Gov_debt & General government gross debt & $\%$ of GDP & $\begin{array}{l}\text { (European } \\
\text { Commission) }\end{array}$ & - \\
\hline NS_fin_educ & $\begin{array}{l}\text { Proxy for the effect of public policies on } \\
\text { financial education: introduction of the } \\
\text { National Strategy of financial education }\end{array}$ & Dummy $(0,1)$ & (OECD, 2015) & + \\
\hline
\end{tabular}

ing their economic structure, geography and demography. Among their noticeable similarities are the characterized economic cycles (Figure 1), economic policies, monetary and banking sectors and population dynamics (Figure 2) (Poissonnier, European Commission, \& Directorate-General for Economic and Financial Affairs, 2017).

The transition to a market economy after recapturing independence shadowed a similar pattern in the Baltics. All three countries followed a common goal to join the EU and the monetary union. Estonia, Latvia and Lithuania have comparatively small government sectors and liberal economic policies. Foreign investors, in no small extent, consider the Baltics as a single market with a single local headquarter and sales policy.

Regarding monetary policy, it should noted that monetary authorities of all three countries strive for a steady exchange rate of their currencies. The Latvian Lat was primarily pegged to the IMF special drawing rights. The Estonian Kroon was pegged to the Deutsche Mark since its introduction in 1992. The Lithuanian Lita was pegged to the US Dollar from 1994. Later all Baltic currencies pegged to the Euro and joined the European exchange rate mechanism (ERMII) in 2004 and 2005 before joining the Euro Area between 2011 and 2015.

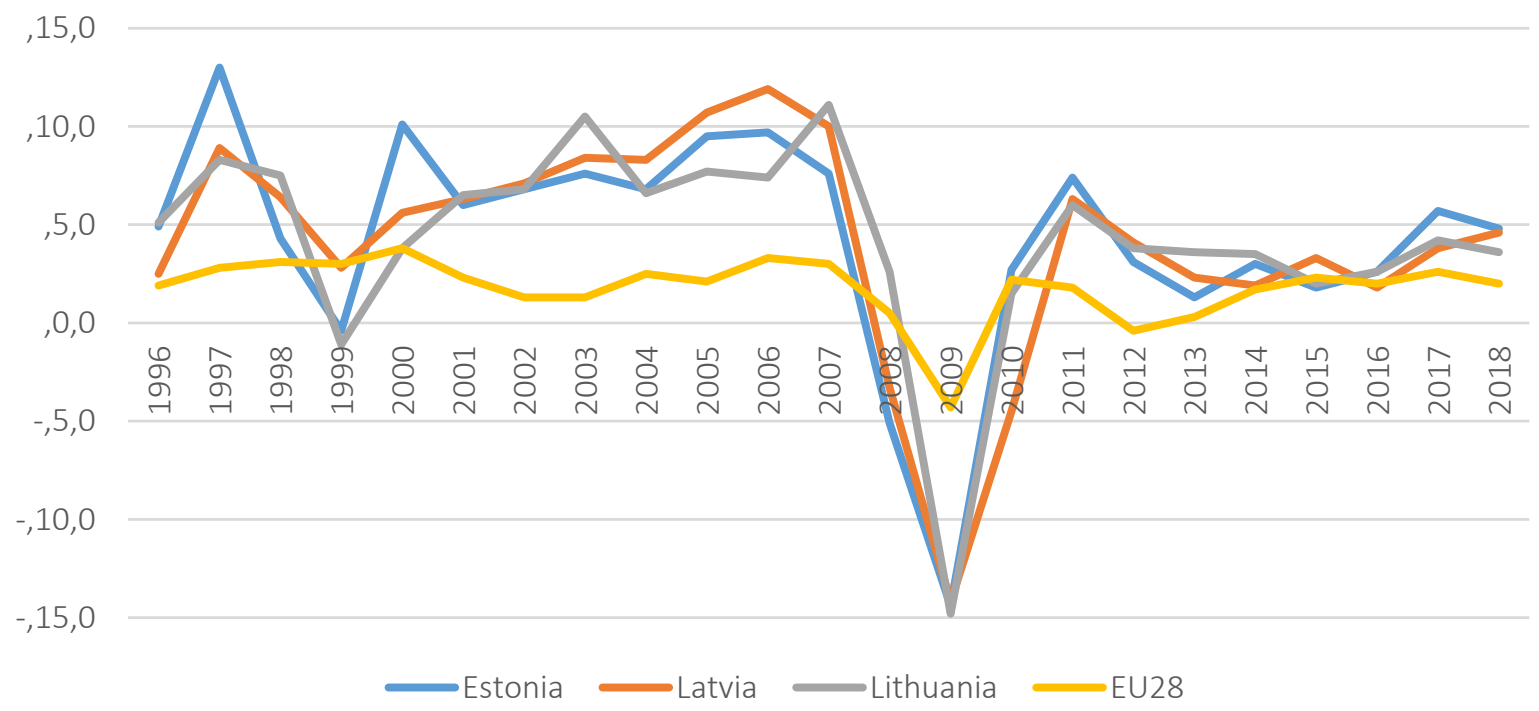

Figure 1. GDP growth rate: volume percentage change on the previous year in the Baltics and EU28, \% 


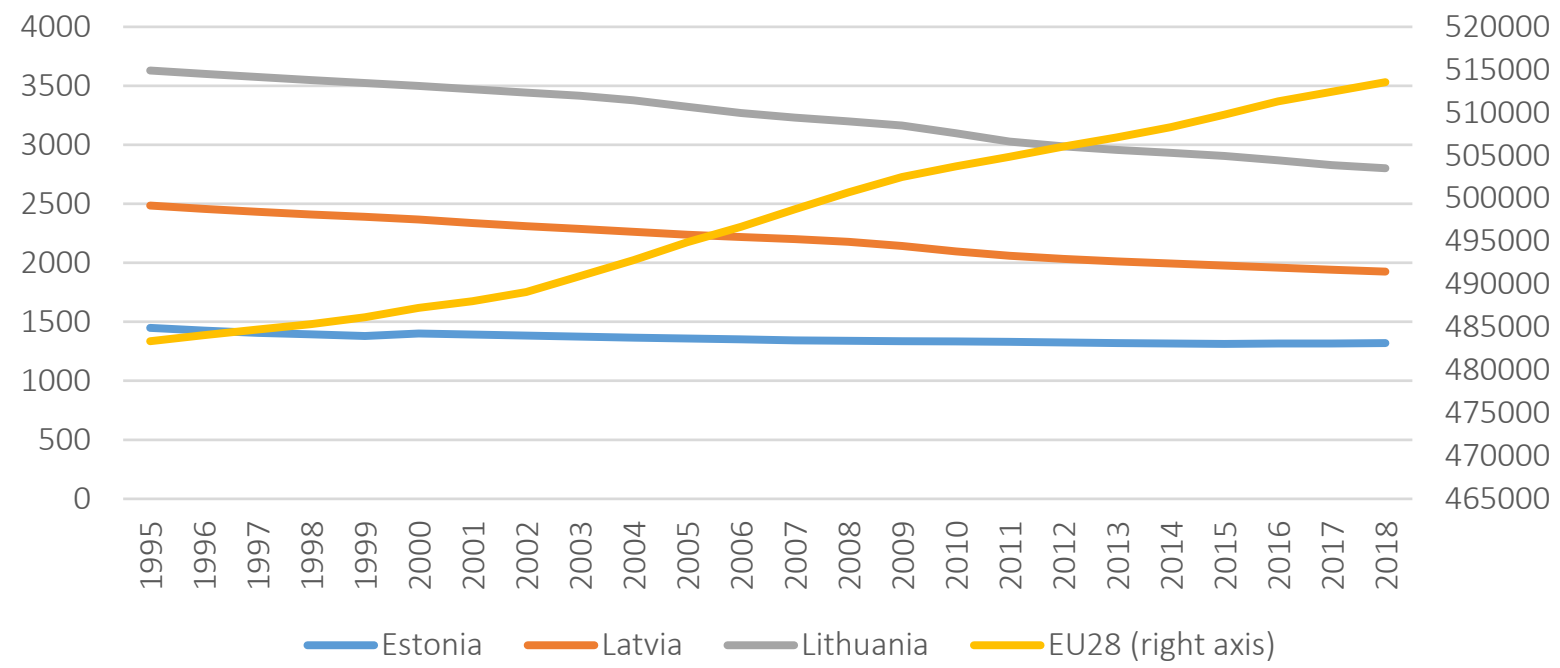

Figure 2. Population dynamics in the Baltics and EU28, thousands

According to statistics, the Baltic countries also demonstrate similar household savings dynamics (Figure 3).

It should be noted that households saving rates need to be interpreted carefully due to data soundness and limited international comparability. Saving rates seem to be in divergence with other economic variables. In particular, household saving rates have been negative over the last twenty years in Romania and Bulgaria, as shown in Figure 3. It means that households in these EU member states spend considerably and interminably more than they earn. However, economic reality does not provide evidence to this, since households debt-to-income ratios stay relatively low in these states and have even been declining since 2009.

Given the typical path of economic development and saving dynamics, the Baltics represent a stable research panel. The next section studies the influence of remittances on household savings in the Baltics.

\section{RESULTS AND DISCUSSION}

The regression analysis has been conducted by employing panel data with the use of fixed effects and

Source: Eurostat.

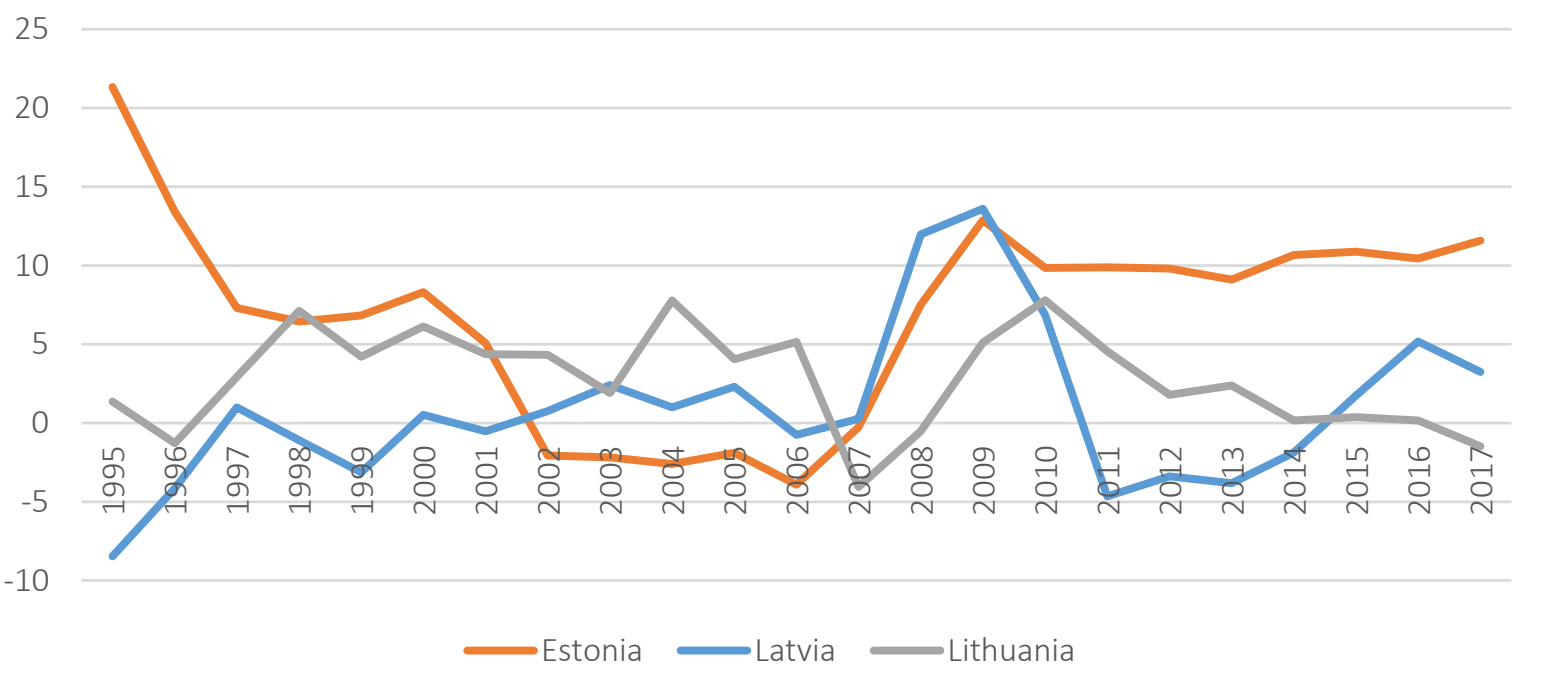

Figure 3. The household saving rate in the Baltics, \% of disposable income 
OLS methods. Summary statistics are represented in Table 2. Regression analysis results are shown in Table 3. The collinearity test is presented in Table 4 , and tests for differing group intercepts, heteroscedasticity and error distribution are shown in Table 5.

Table 2. Summary statistics

\begin{tabular}{|c|c|c|c|c|c|}
\hline Variable & Mean & Median & SD. & Min & Max \\
\hline Savings & 4.22 & 3.90 & 5.33 & -4.65 & 11.6 \\
\hline I_Remmitances & 6.75 & 6.66 & 0.589 & 5.77 & 7.66 \\
\hline I_Life_expect & 2.85 & 2.84 & 0.0415 & 2.78 & 2.93 \\
\hline Unempl_perc & 11.2 & 10.3 & 3.88 & 5.80 & 19.5 \\
\hline Old_age_depend & 27.9 & 27.8 & 1.43 & 25.6 & 30.8 \\
\hline Inflation_HICP & 1.80 & 1.20 & 1.82 & -1.20 & 5.10 \\
\hline FDI_inflow & 3.56 & 3.19 & 3.02 & -3.12 & 13.3 \\
\hline Gov_debt & 29.8 & 39.1 & 15.3 & 6.10 & 47.3 \\
\hline NS fin educ & 0.375 & 0.00 & 0.495 & 0.00 & 1.00 \\
\hline
\end{tabular}

Table 3. Regression results

\begin{tabular}{|c|c|c|c|}
\hline \multirow{3}{*}{$\begin{array}{l}\text { Independent } \\
\text { variables }\end{array}$} & Model 1 & Model 2 & Model 3 \\
\hline & $\begin{array}{c}\text { Baseline } \\
\text { model }\end{array}$ & $\begin{array}{c}\text { Baseline } \\
\text { model }\end{array}$ & $\begin{array}{c}\text { Modified } \\
\text { model }\end{array}$ \\
\hline & Fixed effects & OLS & OLS \\
\hline \multirow{2}{*}{ const } & $448.247^{* *}$ & -66.232 & -46.110 \\
\hline & (192.619) & $(237.646)$ & $(34.534)$ \\
\hline \multirow{2}{*}{ I_Remmitances } & $7.802^{* *}$ & $3.590^{*}$ & $3.640 * *$ \\
\hline & $(2.755)$ & $(1.840)$ & (1.689) \\
\hline \multirow{2}{*}{ I_Life_expect } & $-197.872^{* *}$ & 6.716 & \\
\hline & $(68.186)$ & $(78.423)$ & \\
\hline \multirow{2}{*}{ Unempl_perc } & 0.505 & 0.922 & $0.887^{* *}$ \\
\hline & $(0.375)$ & $(0.538)$ & $(0.342)$ \\
\hline \multirow{2}{*}{$\begin{array}{l}\text { Old_age_- } \\
\text { depend }\end{array}$} & $2.173^{* *}$ & 1.216 & 1.200 \\
\hline & $(0.780)$ & $(1.109)$ & $(1.060)$ \\
\hline \multirow{2}{*}{ Inflation_HICP } & 0.007 & -0.472 & -0.466 \\
\hline & $(0.275)$ & $(0.384)$ & $(0.367)$ \\
\hline \multirow{2}{*}{ FDI_inflow } & $-0.493^{* *}$ & -0.335 & -0.345 \\
\hline & $(0.197)$ & $(0.294)$ & $(0.260)$ \\
\hline \multirow{2}{*}{ Gov_debt } & 0.095 & $-0.519 * *$ & $-0.534^{* * *}$ \\
\hline & $(0.219)$ & $(0.204)$ & $(0.106)$ \\
\hline \multirow{2}{*}{ NS_fin_educ } & 2.030 & 0.766 & 0.761 \\
\hline & $(1.772)$ & $(2.263)$ & $(2.190)$ \\
\hline Observations & 24 & 24 & 24 \\
\hline $\begin{array}{l}\text { Number of } \\
\text { countries }\end{array}$ & 3 & 3 & 3 \\
\hline LSDV R-squared & 0.933 & & \\
\hline $\begin{array}{l}\text { Within } \\
R \text {-squared }\end{array}$ & 0.787 & & \\
\hline$R$-squared & & 0.825 & 0.825 \\
\hline $\begin{array}{l}\text { Adjusted } \\
R \text {-squared }\end{array}$ & & 0.732 & 0.748 \\
\hline
\end{tabular}

Note: Standard errors in parentheses. ${ }^{* * *} p<0.01, * *$ $p<0.05, * p<0.1$.
Table 4. Collinearity test: variance inflation factors

\begin{tabular}{l|c|c}
\hline \multirow{2}{*}{$\begin{array}{c}\text { Independent } \\
\text { variables }\end{array}$} & Model 2 & Model 3 \\
\cline { 2 - 3 } & Baseline model & Modified model \\
\hline I_Remmitances & OLS & OLS \\
\hline I_Life_expect & 3.547 & 3.188 \\
\hline Unempl_perc & 32.079 & \\
\hline Old_age_depend & 13.174 & 5.685 \\
\hdashline Inflation_HICP & 7.618 & 7.418 \\
\hline FDI_inflow & 1.481 & 1.441 \\
\hdashline Gov_debt & 2.385 & 1.996 \\
\hline NS_fin_educ & 29.230 & 8.397 \\
\hline
\end{tabular}

Table 5. Test for differing group intercepts, heteroscedasticity test, error distribution test

\begin{tabular}{|c|c|c|c|}
\hline \multirow{3}{*}{ Tests/Models } & Model 1 & Model 2 & Model 3 \\
\hline & $\begin{array}{l}\text { Baseline } \\
\text { model }\end{array}$ & $\begin{array}{c}\text { Baseline } \\
\text { model }\end{array}$ & $\begin{array}{l}\text { Modified } \\
\text { model }\end{array}$ \\
\hline & Fixed effects & OLS & OLS \\
\hline \multirow{2}{*}{$\begin{array}{l}\text { Test for differing group } \\
\text { intercepts }\end{array}$} & 10.677 & & \\
\hline & $(0.001)$ & & \\
\hline \multirow{2}{*}{$\begin{array}{l}\text { Wald test for } \\
\text { heteroskedasticity }\end{array}$} & 2.159 & & \\
\hline & $(0.54)$ & & \\
\hline \multirow{2}{*}{$\begin{array}{l}\text { White's test for } \\
\text { heteroskedasticity }\end{array}$} & & 21.733 & 20.329 \\
\hline & & $(0.114)$ & $(0.087)$ \\
\hline \multirow{2}{*}{$\begin{array}{l}\text { Test statistic for } \\
\text { normality of residual test }\end{array}$} & 0.186 & 0.799 & 0.874 \\
\hline & $(0.91)$ & $(0.67)$ & $(0.645)$ \\
\hline
\end{tabular}

Model 1 (Table 3) represents the results of fixed effects estimation; Model 2 shows the results of OLS estimation, Model 3 represents the results of OLS estimation with the use of modified baseline model due to detected collinearity problem (Table 4). The variable "life expectancy" has been removed from Model 3. A test for differing group intercepts has defined that fixed effects are a proper estimation method in terms of an employed regression model. Both the Wald test for heteroscedasticity in the case of fixed effects estimation and White's test for heteroscedasticity in the case of OLS estimation have shown that heteroscedasticity is not present. A test statistic for normality of residual test has identified an error that is normally distributed in all estimations.

Both fixed effects and the OLS method have shown that remittances have a strong positive influence on household savings in the Baltics in the post-crisis period from 2010 to 2017.

According to fixed effects, life expectancy was negatively associated with household savings in 
the Baltics, which does not support the expectations. It can be explained by the fact that people anticipate that an increase in life expectancy will be accompanied by an increase in the retirement age or potential pension benefit in the case of delaying the earliest possible retirement time. Hence, they could rely more on their longer work career than on savings. This assumption may also be supported by the fact that the government in most of the EU member states allow the people to work when receiving an old-age pension (Europäische Kommission \& Europäische Kommission, 2018).

The received positive link between old-age dependency and household savings also does not support our assumptions according to which it should be negative. The result received can indicate that population ageing may not result in lower saving rates in the future if the retirement age rises. It can be explained by the fact that the ageing population could wish to support their grand- children or working-aged children. Hence, public pensions can appear as a transfer that supports the household.

Fixed effects estimation demonstrated that the uncertainty indicators - unemployment and inflation - were not significant determinants of household savings in the Baltics. However, an OLS estimation has revealed a positive association between unemployment and savings, which confirms the assumption. Government debt has appeared to be an insignificant regressor in the fixed-effects estimation. However, OLS estimation has revealed a negative link between this variable and household savings, which supports the assumption.

The FDI inflow in fixed effects estimation appeared to be negatively linked to savings, which is following the assumptions. However, in the OLS estimation, this variable was not significant.

\section{CONCLUSION}

This paper identified the influence of remittances on household savings in the Baltics, along with other macroeconomic variables in the post-crisis period. The relative smoothing and convergence of economic development of the Baltic countries can be observed after the sharp economic distress in 2009. The significance of remittances for household savings in the Baltics was studied along with other macroeconomic variables: unemployment rate, inflation, FDI inflows, and government debt and demographic variables: life expectancy, old-age dependency, and the introduction of the National Strategy of financial education as a proxy for financial literacy.

Fixed effects and OLS methods were employed for the regression analysis. Both estimations have revealed that remittances are an essential driver of savings in the Baltics. The estimation with fixed effects association between demographic indicators did not support the hypothesis advanced in this paper. However, the issue lies in the complexity of savings due to high subjectivity.

According to the fixed effects estimation, uncertainty indicators - inflation and unemployment - appeared to be insignificant factors of saving. Among other employed factors, only FDIs are significant. However, OLS estimation results have shown that government debt and unemployment do influence savings.

The fixed effects results indicate that in general savings in the Baltics are not significantly influenced in the short term by sharp economic fluctuations, but are dependent on demographic factors and foreign capital, which can bring instability in economic development and financial flows of the region. Thus, in the light of this, remittances, given their nature described above, are a vital source of savings in the long run. 


\section{AUTHOR CONTRIBUTIONS}

Conceptualization: Andrej Přívara, Karol Trnovský.

Data curation: Andrej Přívara, Karol Trnovský.

Formal analysis: Andrej Přívara, Karol Trnovský.

Funding acquisition: Andrej Př́vara, Karol Trnovský.

Investigation: Andrej Př́vara, Karol Trnovský.

Methodology: Andrej Př́vara, Karol Trnovský.

Project administration: Andrej Přívara, Karol Trnovský.

Resources: Andrej Přívara, Karol Trnovský.

Software: Andrej Př́vara, Karol Trnovský.

Supervision: Andrej Př́vara, Karol Trnovský.

Validation: Andrej Přívara, Karol Trnovský.

Visualization: Andrej Přívara, Karol Trnovský.

Writing - original draft: Andrej Př́vara, Karol Trnovský.

Writing - review \& editing: Andrej Př́vara, Karol Trnovský.

\section{ACKNOWLEDGMENT}

This research was funded by Vega research project no. 1/0037/20: "New challenges and solutions for employment growth in changing socio-economic conditions", and VEGA research project no. 1/0287/19 "Integration of immigrants in EU countries from the point of view of migration policies".

\section{REFERENCES}

1. Akter, S. (2018). Impact of remittance on domestic labour productivity in Bangladesh. Progressive Agriculture, 29(1), 33-44. https:// doi.org/10.3329/pa.v29i1.37478

2. Agunias D. R. (2006). Remittances and Development: Trends, Impacts and Policy Options: A Review of the Literature, Migration Policy Institute: Washington, DC.

3. Ameriks, J., Caplin, A., \& Leahy, J. (2002). Wealth Accumulation and the Propensity to Plan. Retrieved June 2, 2020, from https://core. ac.uk/download/pdf/6690820.pdf

4. Arif, I., Raza, S. A., Friemann, A., \& Suleman, M. T. (2019). The Role of Remittances in the Development of Higher Education: Evidence from Top Remittance Receiving Countries. Social Indicators Research, 141(3), 1233-1243. https://doi. org/10.1007/s11205-018-1857-8

5. Asian Development Bank, \& World Bank. (2018). Migration and Remittances for Development in Asia. https://doi.org/10.22617/ TCS189320
6. Azam, M., Haseeb, M., \& Samsudin, S. (2016). The Impact of Foreign Remittances on Poverty Alleviation: Global Evidence. Economics \& Sociology, 9(1), 264-281. https://doi.org/10.14254/2071789X.2016/9-1/18

7. Ashraf N., Aycinena D., Martinez C., \& Yang D. (2014). Savings in Transnational Households: A Field Experiment among Migrants from El Salvador. Review of Economics and Statistics, 97(2), 332351. https://doi.org/https://doi. org/10.1162/REST_a_00462

8. Baldé, Y. (2011). The Impact of Remittances and Foreign Aid on Savings/Investment in Sub-Saharan Africa: Impact of Remittances and Foreign Aid on Savings. African Development Review, 23(2), 247-262. https://doi.org/10.1111/ j.1467-8268.2011.00284.x

9. Basu, B., \& Rajan, I. (2018). Investment Expenditure Behavior of Remittance Receiving Households: An Analysis Using Reserve Bank of India Data. Migration
Letters, 15(3), 303-320. https://doi. org/10.33182/ml.v15i3.354

10. Batsaikhan, U., \& Demertzis, M. (2018). Financial literacy and inclusive growth in the European Union. Retrieved May 25, 2020, from http://bruegel.org/wp-content/uploads/2018/05/PC-08_2018.pdf

11. Bloom, D., Canning, D., \& Graham, B. (2002). Longevity and Life Cycle Savings. Scandinavian Journal of Economics, 105(3), 319-338. https:// doi.org/10.3386/w8808

12. Carment, D., \& Calleja, R. (2018). Diasporas and Fragile states beyond remittances assessing the theoretical and policy linkages. Journal of Ethnic and Migration Studies, 44(8), 1270-1288. https://doi.org/10.1080/136918 3X.2017.1354157

13. Carvalho, C., Ferrero, A., \& Nechio, F. (2017). Demographic Transition and Low US Interest Rates (FRBSF Economic Letter). Retrieved May 28, 2020 from https://www.frbsf. org/economic-research/files/ el2017-27.pdf 
14. Chezum, B., Bansak, C., \& Giri, A. (2018). Are Remittances Good for Your Health? Remittances and Nepal's National Healthcare Policy. Eastern Economic Journal, 44(4), 594-615. https://doi.org/10.1057/ s41302-018-0106-9

15. Cruz Zuniga, M. (2011). On the Path to Economic Growth, Do Remittances Help? Evidence from Panel VARs. The Developing Economies, 49(2), 171-202. https://doi.org/10.1111/j.17461049.2011.00128.x

16. Devasagayam, P. R., Calderon, F. J. M., \& Motyl, N. A. (2016). A Cross-National Empirical Investigation of Music Streaming Behavior. International Journal of Academic Research in Business and Social Sciences, 6(5), 152-171. https://doi.org/10.6007/IJARBSS/ v6-i5/2123

17. Dvorský, J., Petráková, Z., Polách, J. (2019). Assessing the Market, Financial, and Economic Risk Sources by Czech and Slovak SMEs. International Journal of Entrepreneurial Knowledge, 7(2), 30-40. https://doi.org/10.12345-0008

18. Edwards, S. (1995). Why are Saving Rates so Different Across Countries? An International Comparative Analysis. New York: National Bureau of Economic Research. https:// doi.org/10.3386/w5097

19. Esteves, R., \& Khoudour-Castéras, D. (2011). Remittances, Capital Flows and Financial Development During the Mass Migration Period, 1870-1913. European Review of Economic History, 15(3), Retrieved May 15, 2020, from https://ssrn. com/abstract $=2025019$

20. European Commission. (2018). The 2018 Pension Adequacy Report: current and future income adequacy in old age in the EU. Luxembourg: Publications Office of the European Union.

21. Gani, A. (2016). Remittances and Savings in Asia: Some Empirical Evidence Based on the Life-Cycle Model. Journal of Finance and Economics, 4(1), 24-38. https://doi. org/10.12735/jfe.v4i1p24

22. Grabowska, I., Garapich, M. P., Jaźwińska, E., \& Radziwinow- iczówna, A. (2017). Migrants as Agents of Change, 1-10. https://doi. org/10.1057/978-1-137-59066-4_1

23. Ghosh B. (2006). Migrants' Remittances and Development: Myths, Rhetoric and Realities. Geneva: International Organization for Migration.

24. Gavurova, B., Ivankova, V., Rigel sky, M., \& Přívarová, M. (2020). Relations Between Tourism Spending and Global Competitiveness - an Empirical Study in Developed OECD Countries. Journal of Tourism and Services, 21(11), 38-54. https://doi.org/10.29036/ jots.v11i21.175

25. Haider, M. Z., Hossain, T., \& Siddiqui, O. I. (2016). Impact of remittance on consumption and savings behavior in rural areas of Bangladesh. Journal of Business, 1(4), 25. https://doi.org/10.18533/ job.v1i4.49

26. Hastings, J. S., Madrian, B. C., \& Skimmyhorn, W. L. (2013). Financial Literacy, Financial Education, and Economic Outcomes. Annual Review of Economics, 5(1), 347373. https://doi.org/10.1146/annurev-economics-082312-125807

27. Jappelli, T., \& Padula, M. (2013). Investment in financial literacy and saving decisions. Journal of Banking \& Finance, 37(8), 27792792. https://doi.org/10.1016/j. jbankfin.2013.03.019

28. Kostakis, I. (2013). The Determinants of Householdss Savings During Recession: Evidence from Greece. SSRN Electronic Journal. https://doi.org/10.2139/ ssrn.2323559

29. Kumar, R. R., \& Stauvermann, P. J. (2014). Exploring the Effects of Remittances on Lithuanian Economic Growth. Engineering Economics, 25(3), 250-260. https:// doi.org/10.5755/j01.ee.25.3.6421

30. Kumar, R. R., Stauvermann, P. J., Kumar, N. N., \& Shahzad, S. J. H. (2018). Revisiting the threshold effect of remittances on total factor productivity growth in South Asia: A study of Bangladesh and India. Applied Economics, 50(26), 2860-2877. https://doi.org/10.1080 /00036846.2017.1412074
31. Loayza, N., Schmidt-Hebbel, K., \& Serven, L. (2000). Saving in Developing Countries. World Bank Economic Review, 14(13), 393414. Retrieved June 2, 2020, from https://elibrary.worldbank.org/doi/ abs/10.1093/wber/14.3.393

32. Lusardi, A., \& Mitchell, O. (2011). Financial Literacy and Planning: Implications for Retirement Wellbeing (pp. 17-39) (NBER Working Paper No. 17078). https://doi.org/10.3386/ w17078

33. Lusardi, A. (2004). Saving and the Effectiveness of Financial Education. SSRN Electronic Journal. https://doi.org/10.2139/ssrn.476022

34. Maduekwe, N. I., \& Adesina, F. (2017). Remittances economy, remittances landscape: An analysis of the economic and socioecological implications of remittances to households in South Eastern Nigeria. GeoJournal, 82(1), 139-155. https://doi.org/10.1007/s10708015-9674-y

35. Makhlouf, F. (2019). Is Productivity Affected by Remittances? The Evidence from Morocco: Financial inflows to Morocco. Journal of International Development, 31(2), 211-222. https://doi.org/10.1002/ jid.3398

36. Matuzeviciute, K., \& Butkus, M. (2016). Remittances, Development Level, and Long-Run Economic Growth. Economies, 4(4), 28. https://doi.org/10.3390/economies 4040028

37. Meseguer, C., Ley, S., \& IbarraOlivo, J. E. (2017). Sending money home in times of crime: The case of Mexico. Journal of Ethnic and Migration Studies, 43(13), 21692192. https://doi.org/10.1080/13691 83X.2017.1300052

38. Niculescu-Aron, I., \& Mihăescu, C. (2012). Determinants of Household Savings in EU: What Policies for Increasing Savings? Procedia - Social and Behavioral Sciences, 58, 483-492. https://doi.org/10.1016/j. sbspro.2012.09.1025

39. OECD. (2013). Coping with Emigration in Baltic and East European Countries. Paris: OECD Publishing. https://doi. org/10.1787/9789264204928-en 
40. OECD. (2015). National Strategies for Financial Education. OECD/ INFE Policy Handbook. Retrieved June 1, 2020, from http://www. oecd.org/daf/fin/financial-education/national-strategies-for-financial-education-policy-handbook. htm

41. OECD (2017) Incomes of older people. In OECD, Pensions at a Glance 2017. https://doi. org/10.1787/pension_glance2017-26-en

42. OECD. (2018). The Role and Design of Net Wealth Taxes in the OECD. Paris: OECD Publishing. https://doi. org/10.1787/9789264290303-en

43. Onwuchekwa, R. I. \& Aniocha, M Ch. (2017). Migrant Remittances, Savings and Investments Among Rural Farm Households in Abia State, Nigeria. Journal of Nutritional Ecology and Food Research, 4(1), 28-33 https://doi.org/10.1166/ jnef.2017.1156

44. Pajaron, M. C. (2017). The role of remittances as a risk-coping mechanism: Evidence from agricultural households in rural Philippines. Asian and Pacific Migration Journal, 26(1), 3-30. https://doi. org/10.1177/0117196816680625

45. Poissonnier, A., European Commission, \& Directorate-General for Economic and Financial Affairs. (2017). The Baltics: Three countries, one economy. Retrieved Jun 3, 2020, from http://dx.publications.europa. $\mathrm{eu} / 10.2765 / 763509$

46. Quartey, P., Ackah, C., \& LambonQuayefio, M. P. (2019). Interlinkages between remittance and savings in Ghana. International Journal of Social Economics, 46(1), 152-166. https://doi.org/10.1108/ IJSE-12-2017-0618

47. Raza, S. A. (2015). Foreign Direct Investment, Workers' Remittances And Private Saving In Pakistan: An Ardl Bound Testing Approach. Journal of Business Economics and Management, 16(6), 1216-1234. https://doi.org/10.3846/16111699. 2013.792867

48. Reisch, L. A., \& Zhao, M. (2017). Behavioural economics, consumer behaviour and consumer policy: State of the art. Behavioural Public Policy, 1(02), 190-206. https://doi. org/10.1017/bpp.2017.1

49. Rocher, S., Stierle, M. H., European Commission, \& DirectorateGeneral for Economic and Financial Affairs. (2015). Household saving rates in the EU: Why do they differ so much? Luxembourg: Publications Office.

50. Sabra, M. M. (2016). Remittances Impact on Economic Growth, Domestic Savings and Domestic Capital at the Presence of ODA and FDI in Selected MENA Countries. International Journal of Regional Development, 3(2), 26. https://doi.org/10.5296/ijrd. v3i2.9276

51. Stango, V., \& Zinman, J. (2009). Exponential Growth Bias and Household Finance. The Journal of Finance, 64(6), 2807-2849. https://doi.org/10.1111/j.15406261.2009.01518.x

52. Strielkowski, W., Rausser, G., Bilan, Y., \& Tsevukh, Y. (2018). Migrant remittances and their impact on the economic development of the Baltic States. Geographica Pannonica, 22(3). https:// doi.org/10.5937/22-16988

53. Syed, H., Nigar, S., \& Ullah, S. (2017). An Analysis of Household Saving and Investment Behavior among Different Income Groups in Urban Area of District Peshawar. IBusiness, 9(4), 188202. https://doi.org/10.4236/ ib.2017.94013

54. Temel Nalın, H. (2013a). Determinants of household saving and portfolio choice behaviour in Turkey. Acta Oeconomica, 63(3), 309-331. https://doi.org/10.1556/ AOecon.63.2013.3.3

55. Temel Nalın, H. (2013b). Determinants of household saving and portfolio choice behaviour in Turkey. Acta Oeconomica, 63(3), 309-331. https://doi.org/10.1556/ AOecon.63.2013.3.3

56. van Rooij, M., Lusardi, A., \& Alessie, R. (2011). Financial literacy and stock market participation. Journal of Financial Econom- ics, 101(2), 449-472. https://doi. org/10.1016/j.jfineco.2011.03.006

57. Wadood, S. N., \& Hossain, Md. A. (2017). Microeconomic impact of remittances on household welfare: Evidences from Bangladesh. Business and Economic Horizons, 13(1), 10-29. https://doi.org/10.15208/ beh.2017.02 